\title{
ARTISTIC DESIGN OF A REPRESENTATIVE GROUP OF PREMISES IN PUBLIC BUILDINGS OF LVIV IN THE SECOND HALF OF THE $19^{\text {th }}$ CENTURY
}

\section{МИСТЕЦЬКИЙ ВИСТРІЙ РЕПРЕЗЕНТАТИВНОЇ ГРУПИ ПРИМІЩЕНЬ В ГРОМАДСЬКИХ БУДІВЛЯХ ЛЬВОВА У ДРУГІЙ ПОЛОВИНІ ХІХ СТ.}

(C) Гетьманчук C., 2020

В статті розглянуто характерні риси та особливості мистецького вистрою репрезентативних приміщень громадських будівель Львова у друг. пол. XIX сm. та прослідковано основні фактори, які впливали на їх формування, як в архітектурному, так і в мистецькому плані. Детально висвітлено питання Віденського історизму та його особливостей в оздоблені інтер'єрів, щңо відобразилось і на Львівських об'єктах. Для детальнішого аналізу мистецького вистрою зроблена репрезентативна вибірка 3 ключових громадські споруд, як Львова, так і ̈̈х аналогів в інших містах імперії, до яких увійили: театри, університети, сейми (у випадку з Віднем-парламент), музеї, суди та інші об'єкти, які мають широку репрезентативну групу приміщень. Та виявлено міжс ними спільні трендові напрямки, прямі та опосередковані цитування, як в мистецьких елементах, так і в загальній ордерній композиції. Також висвітлено ключових осіб в мистецтві та архітектурі, які активно були діяли в період другої половини 19 століття у Львові, та зробили вагомий вклад у формування мистецького вистрою. В результаті було виділено та розглянуто такі основні фактори впливу: адміністративний, культурний, мистецький, соціальний та освітній.

Ключові слова: історизм, мистецький вистрій, репрезентативні приміщення, декоративне мистецтво, культурна спадщина.

Постановка проблеми.

В другій половині XIX століття у зв'язку зі зміною політичного-адміністративного устрою Австро-угорської імперії, у Львові розвивають громадські інституції. Починаючи 3 1849 року ключові громадські споруди будуються в стилістичних напрямках історизму. В цьому плані Львів повністю слідує тенденціям, які відбуваються у столичному Відні.

Громадські будівлі Львова другої половини ХІХ століття є добре дослідженими лише в контексті зовнішньої архітектури фасадів, планів та узагальненого стилістичного аналізу і $\epsilon$ упущеною або слабо розглянутою така вагома складова споруд як інтер'єри, які в мистецькому та матеріальному плані є не менш, а може й більш важливі ніж зовнішній вистрій будівель. 
Мистецька оздоба в репрезентативних приміщеннях громадських будівель Львова $є$ дуже часто в незадовільному стані, частково збережена, а подекуди майже втрачена, як і $€$ втраченими чисельні архівні світлини та зображення, описи та документація. Натомість дослідження факторів, що впливали на формування мистецького вистрою репрезентативних приміщень львівських будівель може надати важливу інформацію про відновлення тих чи інших його елементів, або ж слугувати прикладом відновлення інтер'єру в цілому, як в техніко-технологічному так і в естетичному плані.

Тому є потреба у пошуку першопричин, особливостей, спільностей та впливів на формування мистецького вистрою і за результатом виведення закономірностей, що буде корисним для подальших досліджень у сфері реставрації, консервації та відновлення культурної спадщини в такого типу об'єктах. Метою статті $€$ - виявлення основних факторів, що вплинули на формування мистецького вистрою репрезентативної групи приміщень на прикладі ключових громадських будівель Львова другої половини XIX ст.

\section{Аналіз останніх досліджень і публікацій.}

Спеціальних досліджень мистецького вистрою громадських будівель на жаль не проводилося. С. Лінда в своїх статтях «Проблеми стилю в архітектурі львівського історизму», «Історизм та еклектизм в архітектурі: дефініції та розвиток понять» та в розділі книги «Архітектура Львова. Час і стилі. XIII-XXI ст.» розглядає поняття історизму, прослідковує хронологію його формування, географічне поширення, культурні впливи та формує термінологію. (Демків та Лінда, 1999; Лінда, 1998; 2000; 2009) Я. Пурхля з'ясував чинники впливу віденської архітектури на архітектуру Львова кінця ХІХ ст. (Пурхля, 1997). Важливу інформацію 3 архітектури Львова доби історизму містять праці львівських дослідників-архітекторів, опубліковані наприкінці XIX - початку XX ст., (Рудницький, 2003). У праці Ю. Бірюльова «Творчість мулярських майстрів скульпторів-декораторів львівських споруд кінця XIX - початку XX ст.» розглянути особливості формування галузі скульптури та декоративної пластики у сфері архітектури та будівництва (Бірюльов, 2015, с.212) Дослідницькі та технологічні аспекти реставраційного відтворення втраченого декору у репрезентативних приміщеннях колишнього крайового суду Галичини було розглянуто у публікаціях автора та професора Миколи Бевза.

\section{Виклад основного матеріалу.}

Після ряду революційних подій у Австрійській імперії змінюється іiї форма правління, вона стає дуалістичною монархією у вигляді Австро-Угорщини, проявляються певні форми демократі, підвладні землі отримують автономію, але залишаються вірними монарху. Державна політика стає спрямована не на силовий метод утримання земель, а натомість замінюється іншими важелями впливу: економічним, культурним, правовоадміністративним. Відповідно у Відні в 1860 роках починає створюватись новітня забудова центральної частини міста 3 громадськими будівлями, форма і зміст яких відповідала б новітній моделі правління та світогляду. Постають такі будівлі як будинок Опери (1869), будівля парламенту(1883), музей історії мистецтв (1891), музей історії мистецтва (1867), природознавчий музей (1889), віденська фондова біржа (1861), будинок театру (1888) , ратуша (1889), верховний суд (1882) та багато інших (Schoeller and others, 2014). Схожа ситуація спостерігається і у Львові. В другій половині XIX століття, внаслідок зміни політичного-адміністративного устрою Австро-угорської імперії в місті розвиваються громадські інституції. Починаючи з 1849 року ключові громадські будівлі будуються в стилі 
неоренесансну та класицизму з еклектичним поєднанням бароко та рококо, який був складовою загально-європейського мистецького напрямку - історизму .

Історизм у другій половини ХІХ ст. це - світоглядний напрямок, спосіб мислення, який відображав нове бачення через естетичні форми стилів попередніх епох, які формувались в свій час в певній філософській парадигмі, які рефлексували з суспільно політичним строєм держав та імперій Європи у XIX ст. (посилання) Як для архітектури так i для мистецького вистрою приміщень найпоширенішим методом вираження, в цей період, був еклектизм, який поєднував здебільшого суміжні стилі за хронологічним порядком їх появи (до прикладу поєднання романського та готичного стилів або ренесансу, бароко та класицизму) (Демків та Лінда, 1999; Лінда, 1998).

Натомість 3 60-х років ХІХ століття у Львові, постають такі будівлі, як Галицький сейм та головний корпус Львівської політехніки, виконані у стилістиці неоренесансу. Картографічні дані вказують на тещо у 1902 році у Львові знаходилось 110 громадських будівель серед яких 37 храмів та храмових комплексів (монастирі, симінарії, резиденції для духівництва), 11 закладів охорни здоров'я, 10 споруд військового та правоохоронного призначення, 16 шкіл серед яких гімназії та колегіуми, 4 фінансових установ, 11 адмінстративних будівель, 4 вищих навчальних закладів, 4 музеї, 2 театри та 11 будівель іншиз призначень (рис. 1).

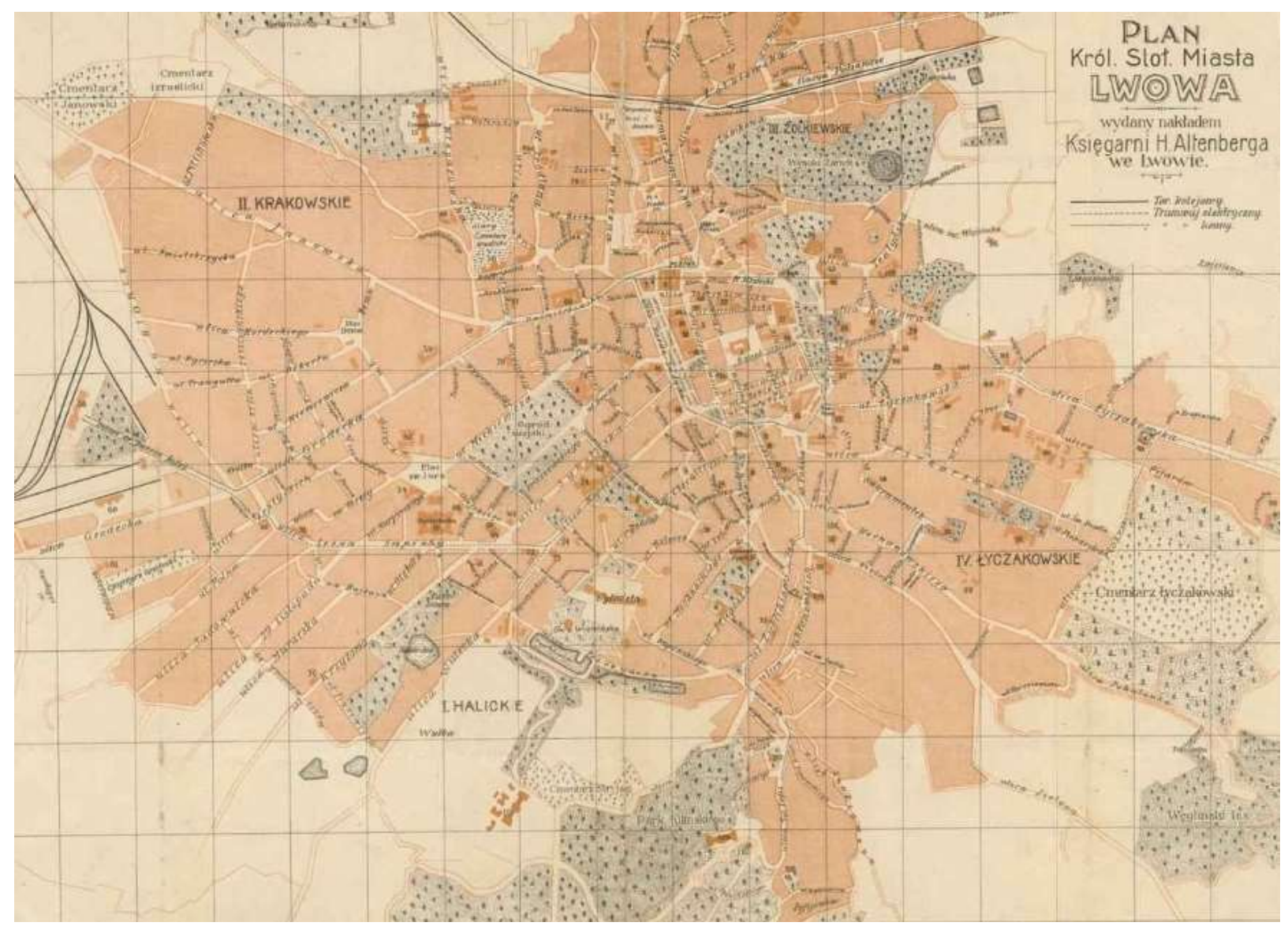

Рис. 1. План Львова 1902 року із зазначеними (темнішим тоном) громадськими будівлями. 3 колекції Ігоря Котлобулатова (Центр міської історії, 2020)

Вибірка об’єктів розглянутих в статті виходить з меж дослідження, та підпадає під такі критерії: хронологічні межі 1850 - 1900 роки, наявність широкої репрезентативної групи приміщень з вестибюлем; багатомаршевою сходовою кліткою, холом або фоє, галереями та залом різного типу призначення. Натурних огляд, архівні фото та плани будівництва $€$ 
основним джерела за якими формувалася характеристика будівель відповідно до меж долслідження. Таким чином було відібрано такі об'єкти: головний корпус Національного університету «Львівська політехніка» (вул. С. Бандери 12), будівля Галицького крайовго сейму (гловний копус Університету імені Івана Франка вул. Університецька 1), Ощадна каса (Етнографічний музей, прп. Свободи 15), Палац правосуддя (19-ий навчальний копус НУ «Львівська політехніка» вул. Князя Романа 1-3), будинок Управління колії (вул. Січових Стрільців 3), споруда Намісництва (Обласна державна адміністраці у Львівській області, вул. Володимира Винниченка 18).
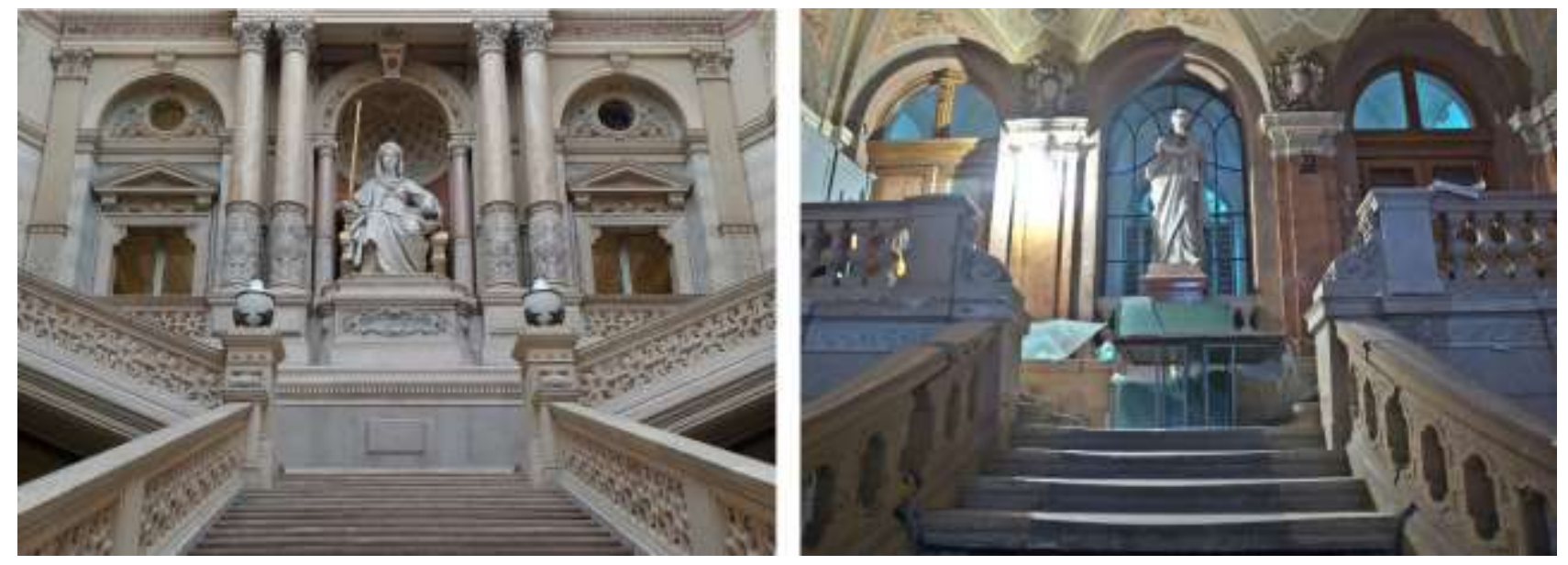

Puс. 1. Мистецький вистрій парадних сходових кліток палаців правосуддя у Відні (з ліва) та у Львові ( з права); фото з приватних збірок автора статmі.

Всі основні громадські будівлі збудовані стилістичних напрямках неоренесансу та неокласицизму з еклектичним поєднанням бароко та рококо, В цьому плані Львів повністю слідує тенденціям, які відбуваються у столичному Відні. Планування, зовнішнє упорядження фасадів громадських будівель Львова створюється за прикладом громадських будівлях в австрійській столиці. Що стосується мистецького вистрою інтер'єрів, то аналогії $\epsilon$ не такими очевидними і однозначним, та складаються з цілого комплексу чинників за якими можна прослідкувати впливи на їх формування. Хоча класичні ордери є звичними для періоду історизму по всій Свропі, проте загальна композиція та присутні елементи декору, вказують на пряме цитування з аналогічних за призначенням та функцією громадських будівель у столиці імперії. До прикладу, у Палаці правосуддя ( вул. Князя Романа 1) малий вестибюль, хоча в цілому має самобутній обрис, але містить запозичення атріуму верховного суду у Відні. Так видно схожість у сходовій клітці, як в плануванні в цілому, сходи $є$ трьох маршеві симетричні з скульптурою Юстиції по центральній осі, та декоративних елементах, пластика виконана в поєднані двох стилів класицизму та ренесансу з сучасними варіаціями, як приклад стовпці з спіральним канелюрами, також проглядається схожість у чергуванні декоративних елементів (поручнів, балясин, акантових кронштейнів) (рис. 2). Також запозичення спостерігаються у інших приміщення репрезентативної групи, де $\epsilon$ присутні неоренесансні розписи, проте вони мають дещо іншу колористику та художні риси.

Однією із перших будівель «нової епохи» була Львівська політехніка, яка була запроектована Ю. Захарієвичем у 1872 році. Проте формування мистецького вистрою репрезентативної групи приміщень відбувалось після завершення будівництва у 1877 році та розтягнулось до кінця 19 століття. Скульптура та ліпний декор інтер'єрів були закладені в проекті і виконувались разом із спорудженням будівлі (рис. 3). 


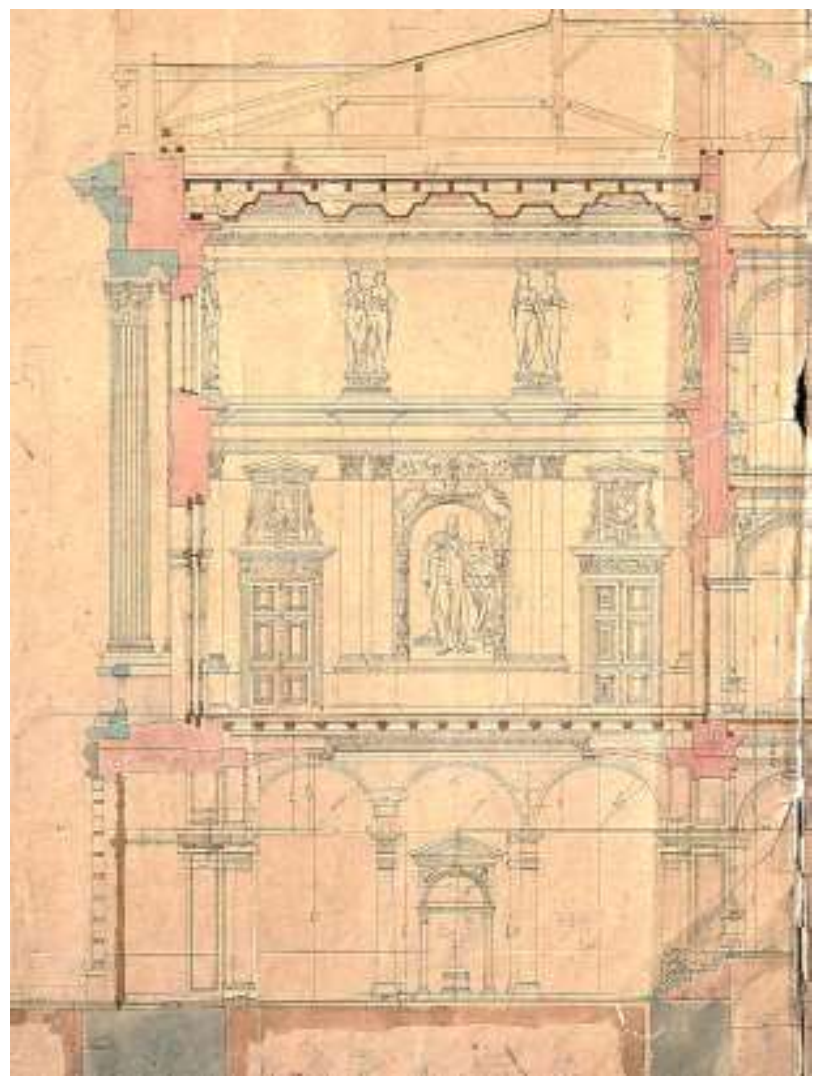

Рисунок 2. Фрагмент креслення перерізу головного корпусу "Львівської політехніки" авторства Ю.Захарієвича, де зображені елменти мистеизького вистрою (Жук, 2008, с. 20).
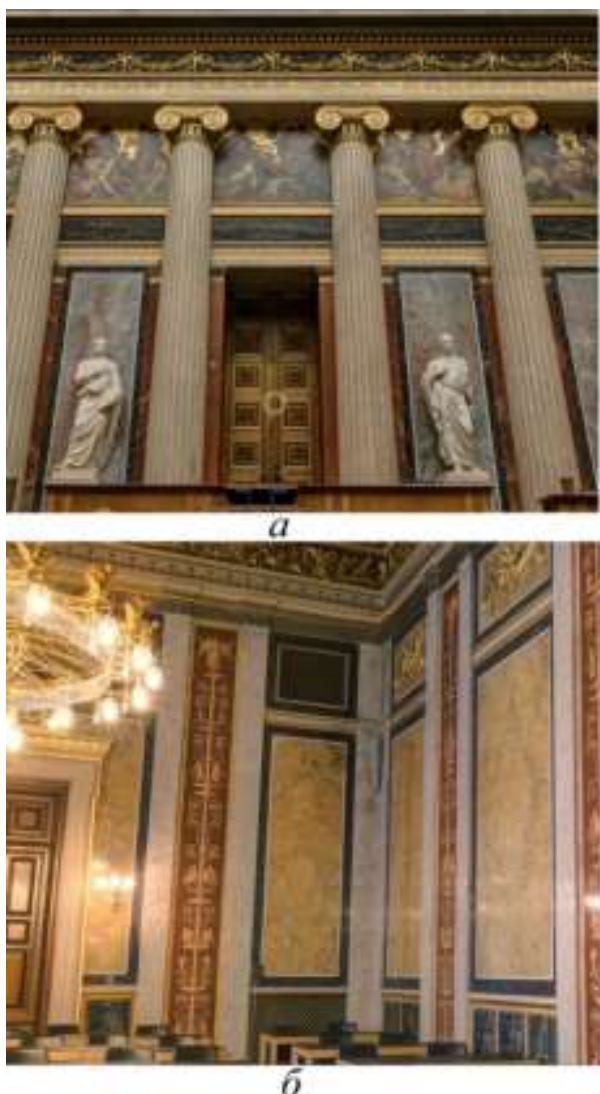

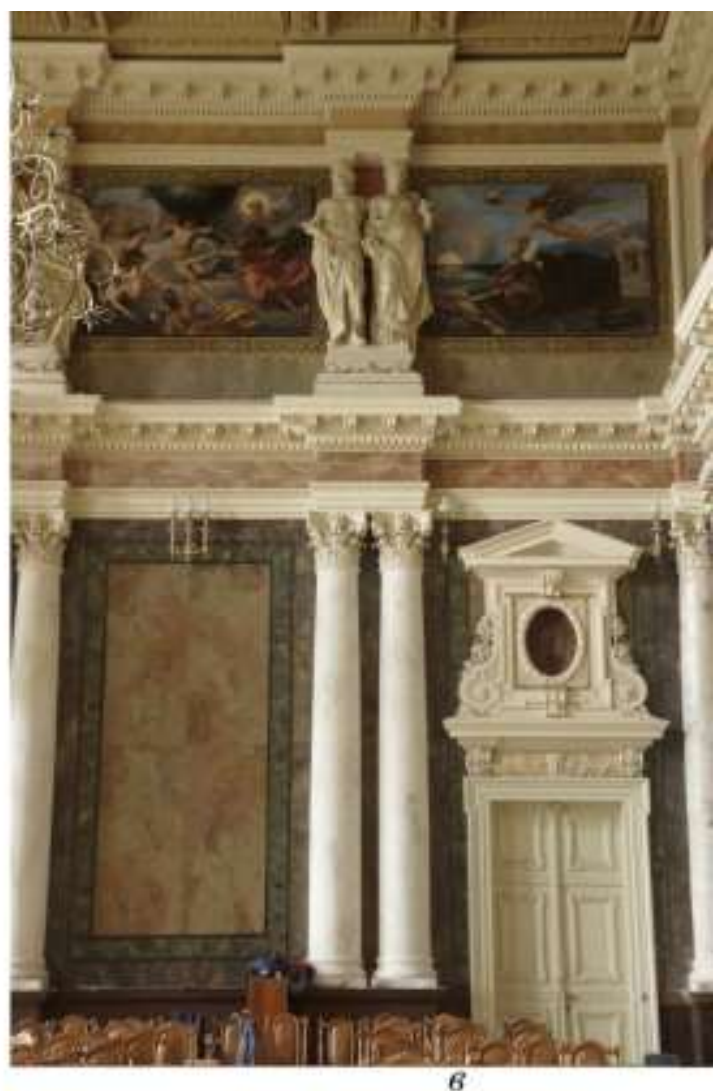

6

Рисунок 4. Фрагменти мистецького вистрою: а) зала засідань віденського парламенту; б) зала засідань міністрів в парламенті; в) актова зала Львівської політехніки; фото з приватних збірок автора статті. 


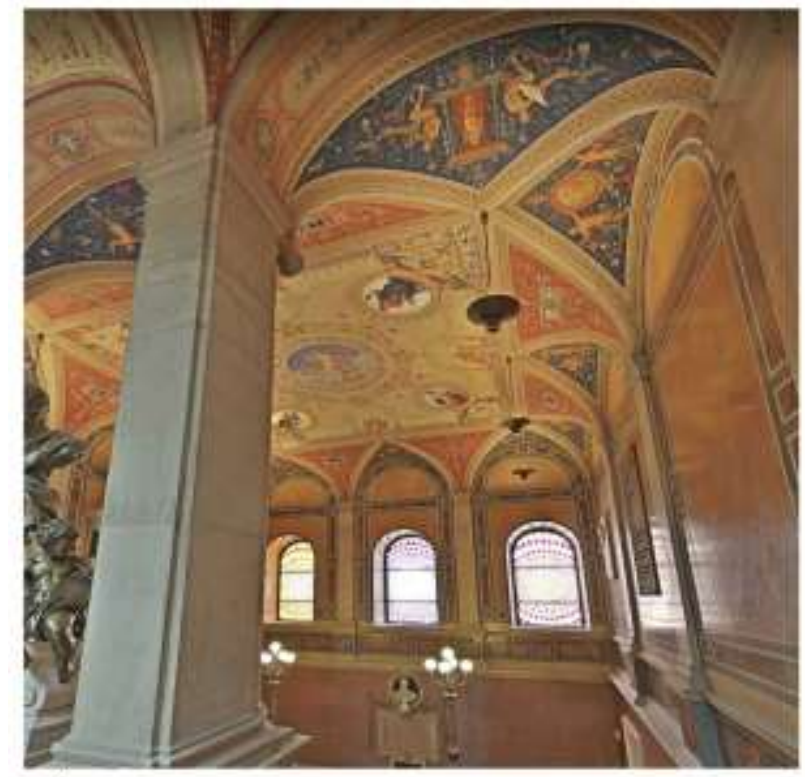

a
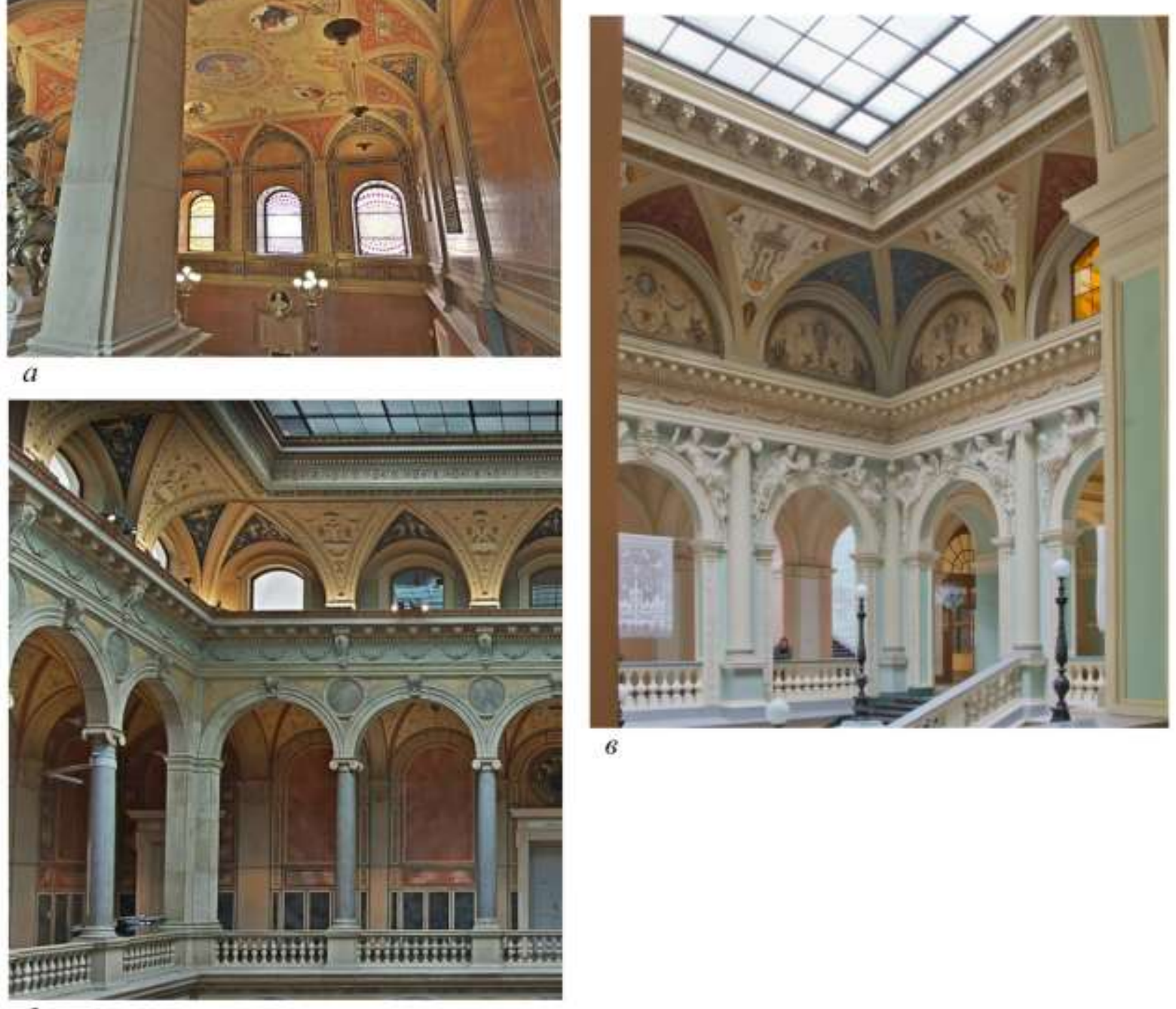

6

6

Рисунок 5. Порівняння мистецьького вистрою вестибюльної групи музею прикладного мистецттва у Відні та Львівської політехніки: а) сходова клітка музею прикладного мистецттва; б)атріум музею прикладного мистеитва; в) сходова клітка Львівської політехніки; фото з приватних збірок автора статті

Зокрема відразу було виконано високомистецьке кесонне ліпне поліхромоване оздоблення стелі актової зали (зали засідань великого сенату). Проте інші елементи мистецького вистрою, такі як художні та альфрейні розписи інтер'єрів, декоративне ліпне оздоблення окремих інтер'єрів, декоративно-ужиткові вироби 3 металу та дерева виконувались більш ніж 10 років після.

За окремим проектом Ю.Захарієвича у 1880-х роках було реалізовано унікальне архітектурно-мистецьке вирішення оздоблення студентського читального залу бібліотеки, яка тоді розміщувалася на другому поверсі головного корпусу. Захарієвичем було запроектовано для цього інтер'єру спеціальну двоярусну бібліотечну шафу на всю довжину зали. Її виготовлено 3 дубового дерева та декоровано різьбленими архітектурними елементами та маскаронами. Стилістика оздоблення шафи перекликається за мотивами 3 
прикладами фламандського маньєризму. Стеля читальної зали виготовлена 3 деревяних елементів та декорована розписами олійними фарбами, імітуючи оздоблення художньою інтарсією в дереві.

На відміно від екстер'єру, який має схожі риси з головною будівлею технічного університету у Відні, на кожному етапі формування мистецького вистрою приміщень відслідковуються різні більш пізні впливи і не однієї, а декількох будівель. Так, присутні запозичення у актовій залі політехніки з оздоблення зали засідань та зали міністрів парламенту у Відні (рис.4). Це стає очевиднішим коли враховувати той факт, що проект оздоблення зали затверджував міністр освіти та віросповідання (Петрій, ред., 2016). Вестибюль та сходова клітка з склепінням мають подібності з віденськими архітектурними реалізаціями другої половини XIX ст. - музеєм історії мистецтв та музеєм прикладного мистецтва. Подібність стосується як планування в цілому, так і ордерної системи, застосування і поєднання різноманітних матеріалів та семантики декоративних пластичних елементів, скульптури та художніх розписів (рис. 5).

Ще одна будівля в якій прочитується вплив Відня це театр Опери та балету, де репрезентативна група приміщень ( вестибюль, сходова клітка, фойє, галереї, дзеркальна зала) має схожу планувальну схему, архітектурну композицію та мистецький вистрій 3 оперним театром у австрійській столиці. Між будівлями $є 32$ роки часового проміжку, що в певній мірі відобразилося на мистецькому вистрої, як у формах декоративних елементів так і в технології їх виконання. Проте загальна неоренесансна композиція прочитується в обох будівлях (рис. 6). Особливо це проявляється в дзеркальній залі де у порівнянні 3 церемоніальною залою віденської опери скульптура, живопис, пластичні елементи, оздоблення з каменю та їі імітації, розміщені за схожою композицією і виконані в подібній колористичній схемі.

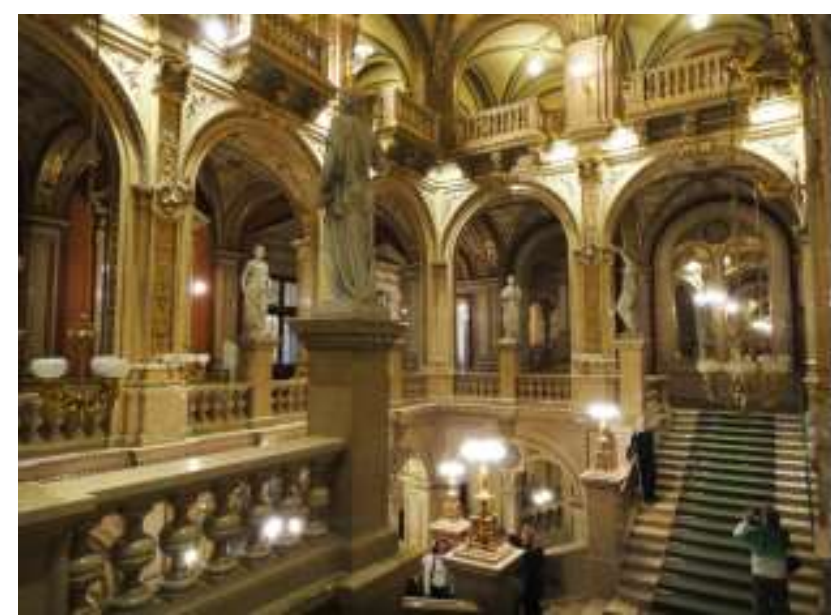

a)

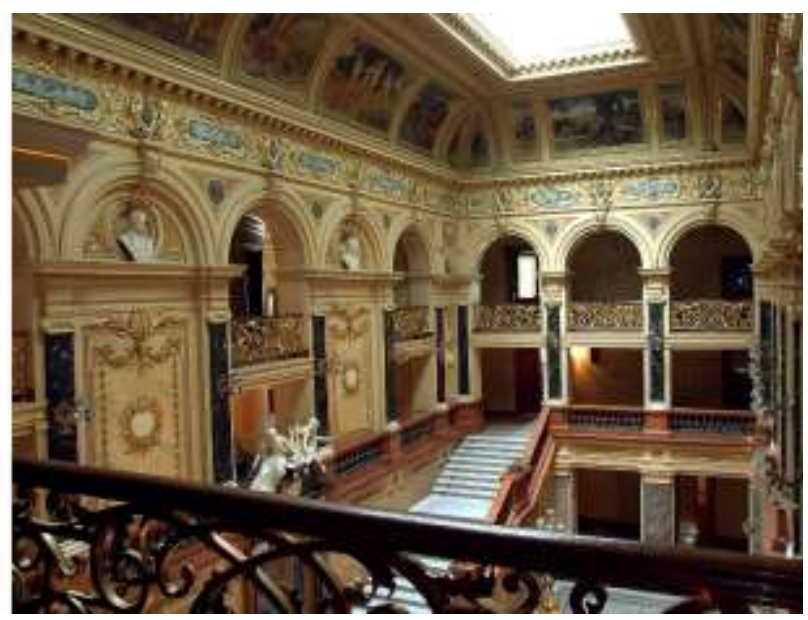

б)

Рисунок 6. Мистецький вистрій холу парадної сходової клітки будинку Опери у Відні (IVPRA, 2015) (a) та y Львові (фото з приватних збірок автора) (б).

Адміністративний вплив на естетичне вирішення інтер'єрів був, як на рівні пропозицій та рекомендацій так і на рівні прямих деректив. До прикладу, в 1887 р. австрійський уряд запропонував ідею організації окремого “консенсу” (патенту, юридичного підтвердження) для скульпторів-мулярів, що правда, після наради у будівельній гільдії її голова архітектор Вінцент Равський-молодший офіційно відхилив пропозицію, вважаючи ії передчасною за його словами мистецтво ліпного декору тільки починалось формуватися, як окрема галузь мулярського ремесла (Бірюльов, 2015). Також яскравими прикладами прямого 
адміністративного вплив є проекти мистецького вистрою ключових громадських будівель Львова, які затверджувались на рівні міністерств культури та віросповідання Австроугорської імперії у Відні. Підтвердженням цьому є такий факт що проект мистецького вистрою актової зали Львівської політехніки затверджував міністр освіти та віросповідання, а Цісарь Франц Йосиф надав замовлення Яну Матейку на виконання серії з 11 картин, котрі мали б увінчувати приміщення зали, на яке було виділено з імперської казни кошти у розмірі 20000 римських золотих (Петрій, І. Я., ред., 2016). В цьому випадку, також можна прослідкувати намагання догодити смакам чиновників з Відня, свідченням цього є те що зала засідань міністрів у австрійському парламентів має схожу ордерну композицію та колористику імітації каменю з мистецьким вистроєм актової зали Львівської політехніки. Разом 3 цим зала, засідань Галицького сейму також мала схожі риси 3 відповідним приміщенням парламенту у Відні, які прослідковуються в розміщенні серії живописних робіт позаду президії та загальному плануванні приміщення, а композиція декоративних елементів вказує на певну єдину тенденцію. Проте з Галицьким сеймом ситуація склалась де що інша, в контексті адміністративного впливу, у порівняні з політехнікою - ініціатором будівництва була місцева влада і відповідно фінансування здійснювалось 3 місцевого бюджету.

Не менш важливим $є$ освітньо-культурний чинник. Ціла плеяда художників, скульпторів та архітекторів які жили і працювали у Львові в друг. пол. XIX ст. були випускниками віденських вузів, таких як: віденська академії мистецтв та школа прикладних мистецтв. Серед них такі відомі імена як: Томаш Ди́кас, Юліян Марковський, Юліан Захаревич, Антон Попель, Тадеуш Попель, Корнило Устиянович, Петро Війтович , Богдан Лепкий, Микола_Івасюк, Северин Обст, Теодо́р Яхимо́вич, Теофі́л Кописти́нський та багато інших. Це можна вважати ключовим фактором який формував стандарти в архітектурі та мистецтві тодішнього Львова, що в свою чергу вплинуло на естетику мистецького вистрою репрезентативних приміщень громадських будівель.

\section{Висновки}

В стилістичному плані мистецький вистрій репрезентативних приміщень громадських будівель Львова слідував загальноєвропейським тенденція історизму, але серед усього найяскравіше прослідковується Віденський вплив, проте львівські споруди і виокремлюються своїми характерними рисами. А саме еклектичне поєднання класицизму та ренесансу, яке проявляється в ритмічних композиціях інтер'єрів із застосуванням в оздоблені широкого спектру видів образотворчого мистецтва. Оскільки, Львів перебував у адміністративній структурі Австрійської частини імперії, він по аналогії з столицею мав відповідний перелік ключових громадських будівель. Порівняльний аналіз вияви багато подібностей, від планувальної схеми приміщень, до декоративно-ужиткових елементів мистецького вистрою, а в деяких випадка зустрічається пряме цитування. Серед основних чинників також виділяється - адміністративний, культурний, освітній та економічний, котрі проявляються, як у вигляді директив та наказів, так і у слідуванні актуальним тенденція того часу в архітектурі та мистецтві. Також вагомим є фактор навчання спеціалістів у Віденських вузах, які згодом стали ключовими особами у формуванні мистецького вистрою інтер'єрів Львова у другій половині ХІХ століття.

У підсумку, можна виділити ряд основних факторі таких, як культурний, освітній, адміністративний та економічний, в яких прослідковується прямий і не прямий вплив столиці імперії на мистецький вистрій громадських будівель Львова. Отже, дослідження 
віденського впливу $є$ важливою складовою в освітленні культурного-мистецького середовища в якому перебував Львів у друг. пол. XIX ст.

\section{Використана література і джерела:}

Бірюльов, Ю. О. 2015. Творчість мулярських майстрів і скульпторів-декораторів львівських споруд кінця XIX - початку XX ст. Вісник Національного університету "Львівська політехніка", Серія: Архітектура. 836, с.212.

Бірюльов, Ю.О., ред., 2008. Архітектура Львова. Час і стилі. ХІІІ-ХХІ ст. Львів: Центр Європи, с. $238-246$.

Демків, М. В. та Лінда, С. М., 1999. Методи стилістичного аналізу історичних об'єктів. Вісник Державного університету «Львівська Політехніка» : архітектура, 375, с.27-31.

Жук, О., 2008 Головна будівля Львівської політехніки. Львів: Видавництво Львівської політехніки.

Лінда, С. М., 1998. Архітектура Львова періоду історизму: закономірності і специфіка розвитку. Вісник Держсавного Університету «Львівська політехніка» : архітектура, 375, с.76-86.

Лінда, С. М., 2000. Проблеми стилю в архітектурі Львіського історизму. Вісник Національного університету "Львівська політехніка", Серія: Архітектура, 410. Львів, с.27-33.

Лінда, С. М., 2009. Історизм та еклектизм в архітектурі: дефініції та розвиток понять. Проблеми теорії та історії архітектури Украӥни, 9, с.74-80.

Петрій, І. Я., ред., 2016. Львівська політехніка у пресі (1844-1900). Львів: Видавництво Львівської політехніки, с.46-73.

Пурхля, Я., 1997. Віденські впливи на архітектуру Львова у 1772-1918. Архітектура Львова у ХІХ ст. Краків, с.31-53.

Рудницький, А. М., 2003. Історія і традиції львівської архітектурної школи. Вісник Державного Університету «Львівська політехніка» : архітектура, 429, с.4-13.

Стасюк, О., 2002. Перший етап формування архітектурних комплексів Празької і Львівської політехніки. Вісник Наџіонального університету «Львівська політехніка»: Архітектура, 439. Львів, с.279-283.

Центр міської історії, 2020. План королівського столичного міста Львова [online] Доступно: < https://uma.lvivcenter.org/uk/maps/34445> [Дата звернення: 1 жовтня 2020]

Grasberger, F. und Knessl, L., 1971. 100 Jahre Goldener Saal. Das Haus der Gesellschaft der Musikfreunde am Karlsplatz. Vienna: Gesellschaft der Musikfreunde.

IVPRA, 2015. Vienna State Opera [online] Avialiable at: < https://ivrpa.org/panorama/vienna-state-opera> [Accessed 1 october 2020]

Michálková, A. and Kašpar, M. 2008. Josef Hlávka, architekt, stavitel a mecenáš patron. Stavebnictví a interiér, 16. pp.50-51.

Schoeller, N and others, 2014. Vienna's Ringstrasse. Vienna.

\section{References:}

Biryul'ov, YU. O. 2015. Creativity of masons and sculptors-decorators of Lviv buildings of the late XIX - early XX centuries. Visnyk Natsional'noho universytetu "L'vivs'ka politekhnika", Seriya: Arkhitektura. 836, p.212.

Biryul'ov, YU.O., ed., 2008. Architecture of Lviv. Time and style. $13^{\text {th }}-21^{\text {st }}$ centuries. L'viv: Tsentr Yevropy, pp. 238 -246.

Demkiv, M. V. and Linda, S. M., 1999. Methods of stylistic analysis of historical objects. Visnyk Derzhavnoho universytetu «L'vivs'ka Politekhnika» : arkhitektura, 375, pp.27-31.

Zhuk, O., 2008. The main building of Lviv Polytechnic. L'viv: Vydavnytstvo L'vivs'koyi politekhniky. 
Linda, S. M., 1998. Architecture of Lviv in the period of historicism: patterns and specifics of development. Visnyk Derzhavnoho Universytetu «L'vivs'ka politekhnika» : arkhitektura, 375, pp.76-86.

Linda, S. M., 2000. Problems of style in the architecture of Lviv historicism. Visnyk Natsional'noho universytetu "L'vivs'ka politekhnika", Seriya: Arkhitektura, 410. L'viv, pp.27-33.

Linda, S. M., 2009. Historicism and eclecticism in architecture: definitions and development of concepts. Problemy teoriyi ta istoriyi arkhitektury Ukrayiny, 9, pp.74-80.

Petriy, I. YA., ed., 2016. Lviv Polytechnic in the Press (1844-1900). L'viv: Vydavnytstvo L'vivs'koyi politekhniky, pp.46-73.

Purkhlya, YA., 1997. Viennese influences on the architecture of Lviv in 1772-1918. Arkhitektura L'vova u XIX st. Krakiv, pp.31-53.

Rudnyts'kyy, A. M., 2003. History and traditions of the Lviv architectural school. Visnyk Derzhavnoho Universytetu «L'vivs'ka politekhnika» : arkhitektura, 429, pp.4-13.

Stasyuk, O., 2002. The first stage of formation of architectural complexes of Prague and Lviv Polytechnics. Visnyk Natsional'noho universytetu «L'vivs'ka politekhnika»: Arkhitektura, 439. L'viv, pp.279-283.

Tsentr mis'koyi istoriyi, 2020. PLAN OF THE ROYAL CAPITAL CITY OF LVIV [online] Avialiable at: <https://uma.lvivcenter.org/uk/maps/34445> [Accessed: 1 October 2020]

Serhii Hetmanchuk accistent of Department of Architecture and Conservation National University "Lviv Polytechnick" email: sergiygetmanchuk@gmail.com ORCID 0000-0001-8831-9750

\section{ARTISTIC DESIGN OF A REPRESENTATIVE GROUP OF PREMISES IN PUBLIC BUILDINGS OF LVIV IN THE SECOND HALF OF THE XIX CENTURY}

(C) Hetmanchuk S., 2020

Abstract. The article considers the characteristic features and distinctness of the artistic design of representative rooms of public buildings in Lviv in second half of $19^{\text {th }}$ century. Traced the main factors that influenced their formation, both architecturally and artistically. Highlighted in detail the Viennese historicism and its features in interior decoration, which is had influenced and reflected to the Lviv's public buildings. For a more detailed analysis of the artistic structure, a representative sample was made of key public buildings, both, in Lviv and their analogues in other cities of the empire. There are was included: theaters, universities, Sejms and parliaments, museums, courts and other buildings, which have a wide representative group of premises. Also highlighted there are common trends, direct and indirect quotations, both in the artistic elements and in the overall composition. In addition, was also show up the key figures in art and architecture who were active in the second half of the $19^{\text {th }}$ century in Lviv who made a significant contribution to the formation of the artistic arrangements of public buildings. Instead, was indicate and considered main impact factors: administrative, cultural, artistic, social and 
educational. There was administrative influence, both direct and indirect. Along with funding from imperial exchequer, the facts of straight directives on the style of decoration of representative premises are known. There was also a direct influence on the formation of schools, workshops and in general on the field of architecture and art. Another important factor is that, both the elites and society was focused in the all spheres of life on the capital of the empire. Especially in the culture, architecture and art. For conclusions, in stylistic terms, the artistic design of representative public buildings in Vienna followed the panEuropean tendency of historicism, but stood out in its characteristic features. Since Lviv was part of the administrative structure of the Austrian part of the empire, by analogy with the capital, it had a corresponding list of key public buildings. Comparative analysis reveals many similarities, from the layout of the premises, to the decorative and applied elements of artistic design, and in some cases there is a direct citation. Among the main factors are administrative, cultural, educational and economic, which are manifested both in the form of directives and in socio-cultural imitation the current trend at that time in architecture and art.

Keywords: historicism, artistic arrangement, representative premises, decorative art, cultural heritage. 